\title{
The Efficacy of Synbiotic Application in Broiler Chicken Diets, Alone or in Combination with Antibiotic Growth Promoters on Zootechnical Parameters
}

\author{
Basharat Syed $^{1 *}$, Silvia Wein ${ }^{1}$ and Yuwares Ruangapanit ${ }^{2}$ \\ 'Biomin Holding GmbH, Erber Campus 1, 3131 Getzersdorf, Austria \\ ${ }^{2}$ Department of Animal Science, Faculty of Agriculture at Kamphaeng Saen, Kasetsart University, Kamphaeng Saen, Thailand \\ ${ }^{*}$ Corresponding author’s Email: basharat.syed@ biomin.net; ORCID: 0000-0002-7365-1344
}

Received: 27 Apr. 2020

Accepted: 09 Aug. 2020

\begin{abstract}
In recent years, probiotics and synbiotics have gained considerable interest in poultry feeding as an alternative to antibiotics due to antibiotic resistance concerns. The objective of this dual study was to evaluate the efficacy of synbiotic supplementation alone or in combination with different Antibiotic Growth Promoters (AGPs), compared to the untreated control group of broiler chickens production performance. In the first experiment, a total of 1260 oneday-old male Ross 308 broiler chickens were randomly assigned to 7 diet treatments, with 6 replicates per diet treatment and 30 birds per replicate over a 42-day period. The diet treatments included a control diet based on cornsoybean without additives (T1), and the diet treatment with bacitracin (BMD $100 \mathrm{ppm}, \mathrm{T} 2)$, colistin (10 ppm, T3), synbiotic (PoultryStar me, $0.5 \mathrm{~kg} / \mathrm{t}, \mathrm{T} 4)$, a combination of synbiotic $(0.5 \mathrm{~kg} / \mathrm{t})$ and bacitracin $(60 \mathrm{ppm}, \mathrm{T} 5)$, synbiotic $(0.5 \mathrm{~kg} / \mathrm{t})$ and colistin $(5 \mathrm{ppm}, \mathrm{T} 6)$, synbiotic $(0.5 \mathrm{~kg} / \mathrm{t})$, bacitracin $(60 \mathrm{ppm})$, and colistin $(5 \mathrm{ppm}$, T7). During the critical period of rearing from hatch to day 10 , the synbiotic supplementation resulted in a significantly higher body weight gain than its combination with bacitracin. No other dietary treatment showed a remarkable improvement in the body weight gain, feed intake, or feed conversion ratio, compared to the only synbiotic application (T4) during the entire trial period. The tendency towards an improved feed conversion ratio was observed during the use of symbiotic (T4, 1.87), compared to the control group ( $\mathrm{T} 1,1.93)$ during the entire trial period. Compared with the control group (T1, 2.78\%), broiler mortality was also lower in the synbiotic group (T4, 1.11\%). In the second experiment, a total of 1500 one-day-old male Ross 308 broiler chickens were randomly assigned to 4 diet treatments; with 15 replicates per diet treatment, and 25 birds per replicate over a 42-day period. The dietary treatments included a control group diet based on corn-soybean without additives (T1), and the treatment diets with bacitracin (BMD $1000 \mathrm{ppm}, \mathrm{T} 2$ ), synbiotic (PoultryStar me, $0.5 \mathrm{~kg} / \mathrm{t}$, T3), and a combination of synbiotic $(0.5 \mathrm{~kg} / \mathrm{t})$ plus bacitracin (BMD $1000 \mathrm{ppm}$ T4). Birds fed antibiotic or synbiotic alone or in a combination had numerically a higher body weight and an average daily gain than the control group. There was a tendency of improvement in the feed conversion ratio during the age of 1-24 days, and throughout the experimental period. The evaluated synbiotic could serve as an effective alternative to AGPs, such as bacitracin and colistin in broiler chicken diets, especially during the first crucial period. The synbiotic can serve this purpose without combining it with AGPs, such as colistin or bacitracin.
\end{abstract}

Keywords: Antibiotic growth promoter, Broilers, Performance, Synbiotic

\section{INTRODUCTION}

In view of the apprehensions of antibiotic resistance, probiotics have gained considerable interest in the poultry industry as alternatives to antibiotics (Gustafson and Bowen, 1997). Presently, this class of feed additives is largely used as an alternative to Antibiotic Growth Promoters (AGP) in poultry feeding. The main impetus that has catalyzed the use of these probiotic feed additives is the worldwide ban on the use of AGPs in the diets of food animals. The alternatives to AGPs should ideally possess the same beneficial effects as AGPs do possess when they are supplemented in the diet of food animals.

Despite the incredulous mechanism of action of the feed antibiotics (Huyghebaert et al., 2011), it is generally believed that the AGPs depict some antibacterial activities, which reduces the incidence and severity of subclinical infections, and decreases the microbial consumption of nutrients, thus improving the absorption of nutrients (Snyder and Wostmann, 1987; Brennan et al., 2003). The subsequent effect of all these activities leads to a better 
performance of the animal. The foundation of this explanation lies in the fact that AGPs do not exert growthpromoting effects in germ-free animals. The prevailing practice of the industry to feed livestock with subtherapeutic doses of antibiotics is unlikely to have a growth inhibitory effect on the resident bacteria (Niewold, 2007). However, when antibiotics were added to the broiler diets at the levels below minimum inhibitory concentration, a clear shift in the intestinal microbiota was observed which at least partly explains the effects of AGPs (Pedroso et al., 2006; Wise and Siragusa, 2007).

Shifts in intestinal microbiota likewise affected the intestinal wall morphology and induced immune reactions which may promote the host animals' growth by affecting their energy expenses (Teirlynck et al., 2009). Thus, AGPalternatives such as probiotics as the hypothetical AGP mode of action should also have modulatory effects on intestinal microbiota and immune system. Probiotics are live microorganisms that should be viable when they are administered in the livestock diets; in order to exert their beneficial effects on an improved intestinal function, intestinal microbiota balance, host immune responses, and the overall host health (FAO and WHO joint working group, 2002).

Dietary probiotics contribute to establish and maintain a beneficial intestinal microbiota, which may enhance the colonization resistance to pathogens, and strengthen the immune responses, leading to an improved growth performance (Dhama et al., 2011; Yang et al., 2012; Mountzouris, 2014; Mountzouris et al., 2015). The path of considering the gastrointestinal tract of food animals as the real complexity of anatomical system playing digestive, absorptive, metabolic, immunological, and endocrinological roles has progressed a lot in the last three decades (Oviedo-Rondon, 2019), the reason why the asseveration gut health became collectively important for the researchers and the livestock industry (Kogut et al. 2017).

The supplementation of probiotics and prebiotics has shown promising results in controlling bacterial infections in poultry by positively influencing the gut microbiota (Mead, 2000). Probiotics competitively excluded pathogenic microbes (Nava et al., 2005) and can be effective by stimulating the immune responses (Koenen et al., 2004), producing antibacterial substances, and stimulating digestive enzymes secretion (Saarela et al., 2000). Synergistic effects could be achieved through socalled synbiotics, a combination of probiotics and prebiotics (Roberfroid, 1998). The combined supplementation of poultry diets with probiotics and prebiotics (synbiotic) has been reported to be more effective than a single supplementation and in some cases even congruous with antibiotic treatments as reported in several studies and reviews (Gaggia et al., 2010; Gadde et al., 2017; Tayeri et al., 2018). Improvements in feed efficiency in broiler chickens as a result of synbiotic supplementation have been attributed to their potential modulatory effect on gastro-intestinal microbial colonization (Brugaletta et al., 2020). Prebiotics are indigestible carbohydrates supplemented frequently in combination with probiotics, which could stimulate the growth of useful bacteria in the intestines of the host (Lee et al., 2016). Prebiotic supplementation was shown to mimic the attachment sites of the pathogens, decreasing the adherence of pathogenic bacteria to the intestinal wall, and increasing specific beneficial bacteria (Ija and Tivey, 1998). Therefore, it draws a great interest to evaluate the effects of a synbiotic on the broiler chicken's performance.

The synbiotic product (PoultryStar me, Biomin Holding $\mathrm{GmbH}$, Austria) evaluated in previous studies contained probiotic bacterial strains of Enterococcus, Bifidobacterium, Pedicoccus, and Lactobacillus species and a prebiotic fructooligosaccharide (Babazadeh et al., 2011).

Given the growth-promoting and immunemodulatory roles of AGPs (Niewold, 2007; Kogut and Swaggerty, 2012; Mountzouris, 2014), the performance response of the broilers to synbiotic products, when experimentally supplemented with AGPs in different combinations had been largely unknown. It was not clear whether there were additive effects due to the combination of AGPs and synbiotics.

The aim of these two experimental trials was therefore to evaluate the effect of dietary inclusion of a specific multi-species poultry synbiotic product alone or in different combinations with Bacitracin and/or Colistin, which are used as AGPs on the performance parameters in broiler chickens.

\section{MATERIALS AND METHODS}

\section{Ethical approval}

All procedures were performed in compliance with relevant laws and institutional guidelines. All animal experiments comply with the ARRIVE guidelines and were carried out in accordance with the U.K. Animals (Scientific Procedures) Act, 1986 and associated guidelines, EU Directive 2010/63/EU for animal experiments. 


\section{First experiment}

\section{Animals and bird husbandry}

A 42-day broiler feeding trial was conducted at the Poultry Research and Development Center of Kasetsart University in Kamphangsaen, Nakhon Pathom, Thailand with a total of 1261 day-old male Ross 308 broiler chickens (with an average body weight of 45 grams at 6hours post-hatching), according to the prevailing institutional ethical norms. The chickens were weighed individually and assigned to seven treatment groups, each comprising of 6 replicates $(n=30$ chickens on the first day). All chickens were raised in floor pens with rice husk as the litter material. Each compartment was equipped with manual feeders and bell-shaped drinkers without nipples. Feed (starter mash from day 1 to 10 , grower mash from day 11 to 24 , finisher mash 1 from day 25 to 35, and finisher mash 2 from day 36 to 42), and water were offered ad libitum. The lighting program was 23-hours light, and 1-hour dark period during the study. The chickens were housed in the evaporative cooling system during the experimental period. The chickens were vaccinated against Newcastle Disease (ND live B1) and Infectious Bronchitis on day 7, Infectious Bursal disease on day 14, and against Newcastle disease (La Sota strain) and Infectious Bronchitis on day 21 again. The temperature was maintained around 32 to $34^{\circ} \mathrm{C}$ for the first week, and then reduced weekly from $34^{\circ} \mathrm{C}$ to $25^{\circ} \mathrm{C}$. The clinical observations regarding the animal health status, as well as the temperature, humidity, ventilation, and lighting of the trial house, were recorded daily during the experimental period.

\section{Experimental diets and treatments}

The trial chickens were randomly assigned to 7 dietary treatments. Each treatment consisted of 6 replications with 30 chickens per replication using a completely randomized design to minimize the effects of group compartments.

All experimental diets were based on the cornsoybean meal. The dietary treatments are presented in tables 1 and 2 .
The ingredients and the chemical composition of the experimental diets are presented in table 3, and the nutrient composition of the experimental diets (proximate analysis) is presented in table 4 . The synbiotic product used in the present study was obtained from Biomin Holding $\mathrm{GmbH}$, Getzersdorf, Austria, and was included in the diet according to the manufacturer's recommendation. The multi-species product symbiotic (PoultryStar ${ }^{\circledR}$ me) contained probiotic bacterial strains of Enterococcus, Pediococcus, Bifidobacterium, and Lactobacillus species as well as a prebiotic fructooligosaccharide.

All the diets were analyzed (AOAC, 2016) for Dry Matter (DM, method 934.01), crude protein (method 988.05), Crude Fiber (method 962.09, CF, Foss Fiber Cap 2021 Fiber Analysis System, Foss Analytical, Hilleroed, Denmark), and crude fat (petroleum ether extraction; method 920.39). Feed samples of each experimental diet prepared for the trial were collected per phase and group immediately after blending and mixing.

\section{Performance parameters measurement}

Chicken live weight was recorded individually for each pen on the days 0, 10, twenty-four, and thirty-five, and per each group on the day forty-two. Body Weight Gain (BWG) was calculated per each group. Furthermore, Feed Intake (FI) was measured for the respective periods in combination with body weight measurements. Hence, the average of FI was determined for the respective periods per each group. Feed Conversion Ratio (FCR) for the respective periods was calculated for each group as the mortality-adjusted ratio between FI and BWG.

\section{Second experiment}

\section{Animals and birds' husbandry}

One thousand five hundred, one day old, male Ross 308 broiler chicks were divided into 4 dietary treatment groups. Each treatment comprised of fifteen replications with twenty-five chickens per replication, and the housing conditions were identical as in the first experimental trial.

\section{Experimental diets and treatments}

All diets were corn-soybean meal, formulated to meet the nutritional requirements recommended by Ross 
308 nutrition specification guide as in the first experiment. The trial began when the birds were one-day-old, and it was finalized when they were forty-two days old. The chickens were divided into 4 dietary treatment groups. Each treatment consisted of fifteen replications with twenty-five birds per replication, followed by a fully randomized design to minimize the effects of group compartments. The dietary treatments are presented in table 2.

The ingredients and the chemical composition of the experimental diets are presented in table 5, and the nutritional composition of the experimental diets (proximate analysis) is presented in table 6 . The synbiotic product used in the present study was similar to the first trial, obtained from Biomin Holding $\mathrm{GmbH}$, Getzersdorf, Austria, and was included in the diet as recommended by the manufacturer. The multi-species product symbiotic (PoultryStar ${ }^{\circledR}$ me) contained probiotic bacterial strains of Enterococcus, Pediococcus, Bifidobacterium, and
Lactobacillus species, and a prebiotic fructooligosaccharide. All other details of the conditions and practices related to the preparations, mixing, and application procedures of the experimental diets were similar to those of the first trial.

\section{Measurement of performance parameters}

The procedures for measuring the performance parameters were the same as described for the first experiment.

\section{Statistical analysis}

The pens were the experimental units, and all data were pooled per pen, unless specified different and expressed as the mean, and pooled the Standard Error of Means (SEM). The data were subjected to a one-way analysis of variance (Statistical Package for Social Sciences, SPSS version 10.1) with the diets as the factor, and it was found to be significant. The means were separated by Duncan's new multiple range test at $\mathrm{p}<0.05$.

Table 1. Description of the Dietary treatments applied to Ross 308 broiler chickens

\begin{tabular}{|c|c|}
\hline Treatment groups & Description \\
\hline $\mathrm{T} 1=$ Negative control $(\mathrm{NC})$ & No additives in feed \\
\hline $\mathrm{T} 2=$ Positive control (PC) 1 (AGP1) & Bacitracin (100 ppm* active ingredient). \\
\hline $\mathrm{T} 3$ = Positive control (PC) 2 (AGP2) & Colistin (10 ppm active ingredient) \\
\hline $\mathrm{T} 4=$ Synbiotic & Synbiotic (PoultryStar me $0.5 \mathrm{~kg} / \mathrm{ton}$ of feed) \\
\hline T5 $=$ Synbiotic + PC $1(\mathrm{PS} * *+\mathrm{AGP} 1 * * *)$ & Synbiotic $0.5 \mathrm{~kg} / \mathrm{ton}$ feed + Bacitracin ( $60 \mathrm{ppm}$ active ingredient) \\
\hline T6 $=$ Synbiotic + PC $2(\mathrm{PS}+\mathrm{AGP} 2 * * * *)$ & Synbiotic $0.5 \mathrm{~kg} / \mathrm{ton}$ feed + Colistin ( $5 \mathrm{ppm}$ active ingredient $)$ \\
\hline $\mathrm{T} 7=$ Synbiotic $+\mathrm{PC} 1+\mathrm{PC} 2(\mathrm{PS}+\mathrm{AGPs})$ & $\begin{array}{c}\text { Synbiotic } 0.5 \mathrm{~kg} / \text { ton feed + Bacitracin (60 ppm active ingredient) } \\
\text { + Colistin (5 ppm active ingredient) }\end{array}$ \\
\hline
\end{tabular}

Table 2. Description of the Dietary treatments applied to Ross 308 broiler chickens

\begin{tabular}{lc}
\hline Treatment groups & Description \\
\hline $\mathrm{T} 1=$ Negative control (NC) & No additives in feed \\
$\mathrm{T} 2=$ Positive control (PC) 1 (AGP) & Bacitracin (BMD*** $\left.10 \% 1000 \mathrm{ppm}^{*}\right)$. \\
$\mathrm{T} 3=$ Synbiotic & PoultryStar $0.5 \mathrm{~kg} / \mathrm{t}^{* * * *}$ of feed \\
\hline $\mathrm{T} 4=$ Synbiotic with AGP** & Poultry Star $0.5 \mathrm{~kg} / \mathrm{t}+$ Bacitracin $(\mathrm{BMD} 10 \% 1000 \mathrm{ppm})$ \\
\hline *ppm: parts per million, **Antibiotic Growth Promoter Bacitracin, $* * *$ Bacitracin methylene di-salicylate, $* * * *$ kilogram per ton
\end{tabular}


Table 3. Ingredient composition and calculated analysis of experimental diets fed to the Ross 308 broiler chickens during the 42day trial in the facility of Kasetsart University.

\begin{tabular}{|c|c|c|c|c|c|}
\hline Ingredients & Unit & $\begin{array}{c}\text { Starter } \\
\text { (Day 1-10) }\end{array}$ & $\begin{array}{c}\text { Grower } \\
\text { (Day 11-24) }\end{array}$ & $\begin{array}{c}\text { Finisher } 1 \\
\text { (Day 25-35) }\end{array}$ & $\begin{array}{c}\text { Finisher } 2 \\
\text { (Day 36-42) }\end{array}$ \\
\hline Corn & $\%$ & 53.40 & 57.17 & 61.69 & 61.69 \\
\hline Soybean meal (46 \% CP) & $\%$ & 30.78 & 25.94 & 19.77 & 19.77 \\
\hline Full fat soybean $(35.5 \% \mathrm{CP})$ & $\%$ & 12.00 & 13.50 & 15.00 & 15.00 \\
\hline Rice bran oil & $\%$ & 0.50 & 0.50 & 1.24 & 1.24 \\
\hline $\operatorname{MDCP}(16.9 \% \mathrm{Ca}, 21.6 \% \mathrm{P})$ & $\%$ & 0.52 & 0.33 & 0.09 & 0.09 \\
\hline Limestone (38.7 \% Ca) & $\%$ & 0.96 & 0.87 & 0.72 & 0.72 \\
\hline Salt & $\%$ & 0.41 & 0.41 & 0.39 & 0.39 \\
\hline Sodium bicarbonate $(27 \% \mathrm{Na}$ ) & $\%$ & 0.05 & 0.05 & - & - \\
\hline Choline chloride $(60 \%)$ & $\%$ & 0.04 & 0.03 & 0.04 & 0.04 \\
\hline Premix & $\%$ & 0.60 & 0.60 & 0.60 & 0.60 \\
\hline L-Lysine & $\%$ & 0.28 & 0.22 & 0.19 & 0.19 \\
\hline DL-Methionine & $\%$ & 0.26 & 0.22 & 0.20 & 0.20 \\
\hline L-Threonine & $\%$ & 0.13 & 0.09 & 0.06 & 0.06 \\
\hline Salinomycin (66 ppm) & $\%$ & 0.05 & 0.05 & 0.05 & - \\
\hline Lutanox & $\%$ & 0.02 & 0.02 & 0.02 & 0.02 \\
\hline Phytase & $\%$ & 0.01 & 0.01 & 0.01 & 0.01 \\
\hline Total & $\%$ & 100.00 & 100.00 & 100.00 & 100.00 \\
\hline \multicolumn{6}{|l|}{ Calculated analysis } \\
\hline ME for poultry & $\mathrm{kcal} / \mathrm{kg}$ & 3053 & 3100 & 3200 & 3200 \\
\hline Protein & $\%$ & 23.00 & 21.50 & 19.50 & 19.50 \\
\hline Fat & $\%$ & 5.02 & 5.41 & 6.54 & 6.54 \\
\hline Fiber & $\%$ & 4.00 & 3.90 & 3.72 & 3.72 \\
\hline Digestible Lysine (Poultry) & $\%$ & 1.28 & 1.15 & 1.02 & 1.02 \\
\hline Digestible Methionine (Poultry) & $\%$ & 0.51 & 0.47 & 0.43 & 0.43 \\
\hline Digestible Threonine (Poultry) & $\%$ & 0.88 & 0.79 & 0.70 & 0.70 \\
\hline Lysine & $\%$ & 1.44 & 1.30 & 1.17 & 1.17 \\
\hline Methionine + Cysteine & $\%$ & 0.92 & 0.87 & 0.80 & 0.80 \\
\hline Methionine & $\%$ & 0.61 & 0.55 & 0.50 & 0.50 \\
\hline Threonine & $\%$ & 0.97 & 0.88 & 0.78 & 0.78 \\
\hline Calcium & $\%$ & 0.80 & 0.72 & 0.61 & 0.61 \\
\hline Total phosphorus & $\%$ & 0.60 & 0.55 & 0.48 & 0.48 \\
\hline Avail. Phosphorus (poultry) & $\%$ & 0.33 & 0.29 & 0.24 & 0.24 \\
\hline Choline & $\%$ & 1700 & 1600 & 1500 & 1500 \\
\hline Sodium & $\%$ & 0.19 & 0.19 & 0.17 & 0.17 \\
\hline Salt & $\%$ & 0.45 & 0.45 & 0.42 & 0.42 \\
\hline
\end{tabular}

$\mathrm{ME}=$ Metabolizable Energy, MDCP = Mono-Dicalcium Phosphate.

Table 4. Nutrient composition of experimental diets (proximate analysis) fed to the Ross 308 broiler chickens during the 42day trial in the facility of Kasetsart University.

\begin{tabular}{lcccc} 
Item & \multicolumn{3}{c}{ Period } \\
& Starter & Grower & Finisher1 & Finisher2 \\
Protein (\%) & 22.31 & 20.54 & 18.25 & 18.68 \\
Fiber (\%) & 4.39 & 4.66 & 4.08 & 3.87 \\
Fat (\%) & 6.01 & 6.26 & 5.49 & 6.08 \\
Ash (\%) & 4.6 & 4.69 & 3.87 & 3.84 \\
Calcium (\%) & 0.79 & 0.8 & 0.63 & 0.57 \\
Phosphorus (\%) & 0.41 & 0.43 & 0.34 & 0.33 \\
GE (kcal/kg) & 4.657 .52 & 4.684 .73 & 4.530 .39 & 4.603 .69 \\
\hline
\end{tabular}

$\mathrm{GE}=$ Gross Energy

\section{RESULTS}

\section{First experiment's results}

All chickens were healthy during the experimental period, and there was no mortality during the most critical period from the hatch to day 10 . The outcome depicted that the synbiotic supplementation in the broiler diet resulted in a significantly higher Body Weight Gain (BWG) than its combination with bacitracin $(\mathrm{p}<0.05)$ during the hatch to day 10 (Table 7). Additionally, the treatment groups T3 (colistin alone) and T6 (colistin with synbiotic) resulted in a significantly better $(\mathrm{p}<0.05)$ BWG 
during this period compared to the control group (Table 7). None of the other treatments improved BWG, FI, or FCR significantly compared to the only synbiotic application (T4) during the entire experimental period from the hatch to day 42 (Table 8). An improved FCR ( $\mathrm{p}=$ 0.0756 ) of 1.86 was observed in the bacitracin group (T2), 1.87 in the symbiotic group (T4), and 1.83 in the synbiotic-AGPs combination group (T7), respectively compared to the control group (T1, 1.93), and other treatment groups during the entire trial period (Table 8). No mortality was observed in the colistin-synbiotic combination group (T6) during the entire trial period. However, remarkably low mortality of $1.11 \%$ occurred in the bacitracin group (T2), the synbiotic group (T4), and the synbiotic-AGPs combination group (T7), respectively during the entire trial period compared to the control group (T1, 2.78\%) and other treatment groups (Table 8).

\section{Second experiment's results}

The birds were healthy throughout the entire experimental trial. The crude protein contents in the mixed feeds corresponded to the calculated values. The amount of crude fat, crude fiber, Calcium (Ca), and phosphorous (P) in the experimental diets also was confirmed well by the calculated values (Table 5). Although no significant differences between the dietary treatments regarding zootechnical parameters were observed, the birds fed only with AGP or synbiotic and AGP in combination with synbiotic had a numerically higher body weight and average daily BWG than the non-supplemented control groups $(p=0.2500)$. This led to a tendency to improve FCR between the age of 1 to twenty-four days old, and throughout the experimental period of 1 to forty-two days (Tables 9 and 10).

Table 5. Ingredient composition and calculated analysis (\%) of the second experimental diets fed to the Ross 308 broiler chickens during the 42-day trial in the facility of Kasetsart University.

\begin{tabular}{|c|c|c|c|c|}
\hline Ingredient & Unit & Starter & Grower & Finisher \\
\hline Corn & $\%$ & 54.75 & 59.52 & 64.30 \\
\hline Soybean oil & $\%$ & 1.92 & 1.72 & 1.50 \\
\hline Full fat Soybean & $\%$ & 8.00 & 10.00 & 12.00 \\
\hline Calcium carbonate & $\%$ & 1.45 & 1.33 & 1.22 \\
\hline МCP-22 & $\%$ & 1.79 & 1.60 & 1.44 \\
\hline L-Lysine & $\%$ & 0.25 & 0.23 & 0.23 \\
\hline Threonine & $\%$ & 0.09 & 0.07 & 0.04 \\
\hline Choline Chloride $60 \%$ & $\%$ & 0.06 & 0.06 & 0.05 \\
\hline Antioxidant & $\%$ & 0.01 & 0.01 & 0.01 \\
\hline Toxin Binder & $\%$ & 0.15 & 0.15 & 0.15 \\
\hline Protein & $\%$ & 23.00 & 21.00 & 19.00 \\
\hline Moisture & $\%$ & 10.92 & 10.97 & 11.03 \\
\hline Fat & $\%$ & 5.93 & 6.24 & 6.53 \\
\hline Fiber & $\%$ & 3.15 & 3.20 & 3.26 \\
\hline Ash & $\%$ & 5.80 & 5.31 & 4.86 \\
\hline $\mathrm{Ca}$ & $\%$ & 0.96 & 0.87 & 0.79 \\
\hline Total P & $\%$ & 0.77 & 0.71 & 0.65 \\
\hline $\mathrm{P}$ avail & $\%$ & 0.48 & 0.44 & 0.40 \\
\hline Salt & $\%$ & 0.36 & 0.35 & 0.35 \\
\hline Lysine & $\%$ & 1.44 & 1.29 & 1.16 \\
\hline Methionine & $\%$ & 0.67 & 0.61 & 0.55 \\
\hline
\end{tabular}

$\mathrm{ME}=$ Metabolizable Energy, $\mathrm{MCP}=$ Monocalcium Phosphate 22\% feed grade 
Table 6. Nutrient composition of the second experimental diets (proximate analysis) fed to the Ross 308 broiler chickens during the 42-day trial in the facility of Kasetsart University.

\begin{tabular}{|c|c|c|c|c|}
\hline $\begin{array}{ll}\text { Starter } & \text { Nutrient }(\%)\end{array}$ & Treatment 1 & Treatment 2 & Treatment 3 & Treatment 4 \\
\hline Moisture & 11.60 & 11.29 & 11.48 & 11.34 \\
\hline Protein & 21.93 & 21.48 & 21.93 & 22.31 \\
\hline Fat & 5.98 & 5.70 & 5.48 & 5.52 \\
\hline Fiber & 2.38 & 2.44 & 2.40 & 2.39 \\
\hline Ash & 5.81 & 5.77 & 5.72 & 5.69 \\
\hline Calcium & 1.01 & 0.97 & 1.00 & 1.00 \\
\hline Phosphorus & 0.80 & 0.74 & 0.78 & 0.77 \\
\hline $\mathrm{GE}(\mathrm{kcal} / \mathrm{kg})$ & 4092.82 & 4106.91 & 4174.68 & 4187.77 \\
\hline \multicolumn{5}{|l|}{ Grower } \\
\hline Moisture & 11.44 & 11.29 & 10.76 & 11.18 \\
\hline Protein & 19.77 & 19.78 & 20.10 & 19.72 \\
\hline Fat & 5.96 & 6.08 & 6.13 & 6.01 \\
\hline Fiber & 2.03 & 2.06 & 2.15 & 1.95 \\
\hline Ash & 6.23 & 6.32 & 6.31 & 6.16 \\
\hline Calcium & 0.89 & 0.91 & 0.88 & 0.92 \\
\hline Phosphorus & 0.71 & 0.74 & 0.73 & 0.71 \\
\hline $\mathrm{GE}(\mathrm{kcal} / \mathrm{kg})$ & 4147.89 & 4180.21 & 4238.82 & 4230.72 \\
\hline \multicolumn{5}{|l|}{ Finisher } \\
\hline Moisture & 12.01 & 12.02 & 11.75 & 11.70 \\
\hline Protein & 18.90 & 18.78 & 18.98 & 18.67 \\
\hline Fat & 6.70 & 6.65 & 6.40 & 6.52 \\
\hline Fiber & 2.06 & 2.22 & 2.02 & 2.12 \\
\hline Ash & 4.82 & 4.83 & 4.89 & 4.94 \\
\hline Calcium & 0.80 & 0.82 & 0.82 & 0.79 \\
\hline Phosphorus & 0.63 & 0.63 & 0.64 & 0.61 \\
\hline $\mathrm{GE}(\mathrm{kcal} / \mathrm{kg})$ & 4373.33 & 4385.00 & 4253.81 & 4218.67 \\
\hline
\end{tabular}

GE = Gross Energy, ME = Metabolizable Energy

\section{DISCUSSION}

Presently, probiotics are largely used as alternatives to antibiotic growth promoters (AGP) in the modern poultry nutrition due to concerns of antibiotic resistance, and the ban imposed on the usage of AGPs in the diets of food animals. Beneficial effects of single or multi-species probiotics on the zootechnical performance of broiler chickens were increasingly documented in the scientific literature (Applegate et al., 2010; Fuentes et al., 2013; Zhang and Kim, 2014; Gadde et al., 2017; Tayeri et al., 2018). The data strongly suggested an improvement in health throughout the experimental period and the complete absence of mortality during the most critical period of day 0 to 10 (Table 7). This is in concordance with studies by Pelicano et al. (2004), and Takahashi et al. (2005), in which the use of different growth promoters in the early phase of rearing led to no differences in the viability and mortality rates of the broiler chickens. The present results indicated that the synbiotic supplementation in the diets of broiler chickens resulted in a significantly higher BWG than the combination with bacitracin $(p<0.05)$ during the first days of the post-hatch brooding period, considered the most critical phase of rearing from hatch to day 10 (Table 7). Probiotics are known to contribute towards the establishment and maintenance of a beneficial intestinal microbiota, which could enhance the colonization resistance to pathogens, and immune response improvements resulting in improved growth performance (Mountzouris, 2014; Mountzouris et al., 2015; Kogut et al. 2017; Baldwin et al., 2018; OviedoRondon, 2019; Brugaletta et al., 2020).

The body weight gain was significantly better ( $\mathrm{p}<$ 0.05 ) in T3 (colistin alone) and T6 (colistin with synbiotic) treatment groups compared to the control groups during this critical period from hatch to day 10 of age (Table 7). Synergistic effects were observed by feeding synbiotics, which are a combination of probiotics and prebiotics (Roberfroid, 1998; Gaggia et al., 2010; Gadde et al., 2017; Tayeri et al., 2018). There was not any significant improvement in BWG, FI, or FCR in any other group compared to the only synbiotic application (T4) during the entire study period from the hatching day to the day fortysecond (Table 8).

An improved FCR ( $\mathrm{p}=0.0756)$ of 1.86 was observed in the bacitracin group (T2), 1.87 in the synbiotic group 
(T4), and 1.83 in the synbiotic-AGPs combination group (T7), respectively compared to the control group (T1, 1.93), and other treatment groups in the study (Table 8). No mortality was recorded in the colistin-synbiotic combination group (T6) during the entire trial period. In the bacitracin group (T2), the synbiotic group (T4), and the synbiotic-AGPs combination group (T7), however, a very low bird mortality rate of $1.11 \%$ occurred compared to the control group (T1, 2.78\%), and other treatment groups (Table 8). Chickens in the second experimental trial were also healthy during the entire study. Although no significant differences among the dietary treatments regarding zootechnical parameters were observed, birds fed with AGP or synbiotic alone, and their combination, had a numerically higher body weight and average daily BWG than that of the control groups $(\mathrm{p}=0.2500)$. This improvement in the BWG in these treatment groups tended to improve FCR in the chickens aged 1 to twentyfour days, and 1 to forty-two days old throughout the experimental period (Tables 9 and 10). No significant differences in body weight, FI, FCR, and mortality among the synbiotic, colistin, and bacitracin groups alone or in combination with each other revealed that AGP could be replaced by synbiotics without loss of zootechnical performance.

Table 7. Effect of the combination of synbiotics with antibiotic growth promoters on the production performance of broiler chickens from day of hatch to day 10 .

\begin{tabular}{|c|c|c|c|c|}
\hline Treatment groups $^{1}$ & $\begin{array}{c}\text { BWG } \\
\text { (g/bird) }\end{array}$ & $\begin{array}{c}\text { FI } \\
\text { (g/bird) }\end{array}$ & FCR & Mortality (\%) \\
\hline $\mathrm{T} 1$ & $192.656^{\mathrm{ab}}$ & 263.472 & 1.36 & 0.00 \\
\hline $\mathrm{T} 2$ & $193.094^{\mathrm{ab}}$ & 272.611 & 1.41 & 0.00 \\
\hline $\mathrm{T} 3$ & $199.133^{\mathrm{a}}$ & 271.389 & 1.36 & 0.00 \\
\hline $\mathrm{T} 4$ & $198.461^{\mathrm{a}}$ & 270.217 & 1.36 & 0.00 \\
\hline T5 & $186.050^{\mathrm{b}}$ & 272.361 & 1.46 & 0.00 \\
\hline T6 & $199.678^{\mathrm{a}}$ & 267.611 & 1.34 & 0.00 \\
\hline $\mathrm{T} 7$ & $193.189^{\mathrm{ab}}$ & 265.583 & 1.37 & 0.00 \\
\hline $\mathrm{p}$-value & 0.0337 & 0.6047 & 0.1492 & 0.00 \\
\hline SEM & 1.2663 & 1.5107 & 0.0129 & 0.00 \\
\hline
\end{tabular}

$\overline{\mathrm{a}, \mathrm{b}}$ Means with dissimilar letters in a column varied significantly $(\mathrm{p}<0.05)^{1} \mathrm{~T} 1=$ No additives in feed, T2 = Bacitracin, T3 = Colistin, T4 = Synbiotic $\left(\right.$ PoultryStar ${ }^{\circledR}$ me), T5 = Synbiotic + Bacitracin, T6 = Synbiotic + Colistin, T7 = Synbiotic + Bacitracin + Colistin. BWG $=$ Body Weight Gain, FI = Feed Intake, FCR $=$ Feed Conversion Ratio, SEM = Standard Error of Means

Table 8. Effect of the combination of synbiotics with antibiotic growth promoters on the production performance of broiler chickens from the first day to day 42 .

\begin{tabular}{|c|c|c|c|c|}
\hline \multirow{2}{*}{ Treatment groups ${ }^{1}$} & BWG & FI & \multirow{2}{*}{ FCR } & \multirow{2}{*}{ Mortality (\%) } \\
\hline & (g/bird) & (g/bird) & & \\
\hline $\mathrm{T} 1$ & 2872.50 & 5547.01 & 1.93 & 2.78 \\
\hline $\mathrm{T} 2$ & 2921.17 & 5435.59 & 1.86 & 1.11 \\
\hline $\mathrm{T} 3$ & 2871.02 & 5540.05 & 1.93 & 1.67 \\
\hline $\mathrm{T} 4$ & 2923.90 & 5479.02 & 1.87 & 1.11 \\
\hline T5 & 2883.07 & 5412.70 & 1.88 & 1.67 \\
\hline $\mathrm{T} 6$ & 2893.12 & 5444.65 & 1.88 & 0.00 \\
\hline $\mathrm{T} 7$ & 2972.42 & 5453.08 & 1.83 & 1.11 \\
\hline p-value & 0.7736 & 0.6241 & 0.0756 & 0.4758 \\
\hline SEM & 18.1249 & 22.4774 & 0.0096 & 2.2160 \\
\hline
\end{tabular}


Table 9. Effect of dietary treatments on growth performance of Ross 308 broiler chickens from day 1 to day 24 , fed in the facility of Kasetsart University.

\begin{tabular}{|c|c|c|c|c|c|}
\hline Treatment & Feed intake (g) & Body weight (g) & $\begin{array}{c}\text { ADG } \\
\text { (g/bird/day) }\end{array}$ & FCR & \% Livability \\
\hline $\mathrm{NC}$ & 1720.573 & 1013.843 & 42.243 & 1.698 & 99.733 \\
\hline AGP & 1717.280 & 1021.277 & 42.553 & 1.682 & 100.000 \\
\hline PS & 1721.093 & 1021.189 & 42.550 & 1.687 & 99.733 \\
\hline $\mathrm{PS}+\mathrm{AGP}$ & 1721.107 & 1020.827 & 42.534 & 1.686 & 99.733 \\
\hline p-value & 0.9818 & 0.8752 & 0.8752 & 0.6611 & 0.8013 \\
\hline SEM & 3.7512 & 3.7136 & 0.1547 & 0.0047 & 0.1135 \\
\hline
\end{tabular}

$\mathrm{NC}=$ negative control, no additives in feed, PS $=$ PoultryStar ${ }^{\circledR}$ me, AGP $=$ antibiotic growth promoters, Bacitracin, ADG = average daily weight gain, FCR $=$ feed conversation ratio, $\mathrm{SEM}=$ Standard Error of the mean, $\mathrm{g}=$ gram

Table 10. Effect of dietary treatments on growth performance of Ross 308 broiler chickens from day 1 to day 42 , fed in the facility of Kasetsart University.

\begin{tabular}{lccccc}
\hline Treatment & Feed intake $(\mathbf{g})$ & Body weight $(\mathbf{g})$ & $\begin{array}{c}\text { ADG } \\
\text { (g/bird/day) }\end{array}$ & FCR & Livability $(\%)$ \\
\hline NC & 4740.160 & 2536.299 & 61.403 & 1.841 & 99.200 \\
AGPs & 4722.093 & 2572.408 & 62.196 & 1.811 & 99.733 \\
PS & 4724.067 & 2548.600 & 61.697 & 1.824 & 99.467 \\
PS + AGPs & 4751.960 & 2565.667 & 62.103 & 1.824 & 99.733 \\
\hline p -value & 0.8165 & 0.3723 & 0.3732 & 0.2500 & 0.6368 \\
SEM & 12.4302 & 20.4605 & 0.4876 & 0.0115 & 0.1672 \\
\hline
\end{tabular}

$\mathrm{NC}=$ negative control, no additives in feed, PS $=$ PoultryStar ${ }^{\circledR}$ me, AGP $=$ antibiotic growth promoters, Bacitracin, ADG = average daily weight gain, FCR = feed conversation ratio, $\mathrm{SEM}=$ Standard Error of the mean, $\mathrm{g}=$ gram

\section{CONCLUSION}

Overall, the results of these two experiments under the controlled conditions proved that the evaluated synbiotic (PoultryStar ${ }^{\circledR}$ me) could serve as a replacement and an effective alternative to the Antibiotic Growth Promoters (AGPs), such as bacitracin and colistin in the broiler diets. With careful evaluation and the right preventive programs, the synbiotic can serve this purpose without being combined with AGP's. Hence, the replacement could be cost-effective and bring more value to broiler chicken producers.

\section{DECLARATIONS}

\section{Authors' contribution}

The experimental studies were conceived and designed by Basharat Syed and Yuwares Ruangapanit in consultation with Silvia Wein. Yuwares Ruangapanit supervised the experimental trials, collection of data, and its analysis. Silvia Wein reviewed the statistical analysis. The manuscript was written and drafted by Basharat Syed. All authors read and approved the final manuscript for submission and publication.

\section{Competing interests}

The authors declare that they have no competing interests.

\section{Acknowledgements}

The authors acknowledge the financial support for the experimental studies extended by BIOMIN Holding $\mathrm{GmbH}$, Austria, and the Poultry Research and Development Center of Kasetsart University in Kamphangsaen, Nakhon Pathom, Thailand for the technical support.

\section{REFERENCES}

Applegate T, Klose V, Steiner T, Ganner A, and Schatzmayr G (2010). Probiotics and phytogenics for poultry: Myth or reality? Journal of Applied Poultry Research, 19: 194-210. DOI: https://doi.org/10.3382/japr.2010-00168

Babazadeh D, Vahdatpour T, Nikpiran H, Jafargholipour MJ and Vahdatpour S (2011). Effects of probiotic, prebiotic and symbiotic intake on blood enzymes and performance of Japanese quails (Coturnix japonica). Indian Journal of Animal Science, 81: 870$874 . \quad$ Available at: http://epubs.icar.org.in/ejournal/index.php/IJAnS/article/view/879 $\underline{9}$

Baldwin S, Hughes RJ, Van TTH, Moore RJ, and Stanley D (2018). Athatch administration of probiotic to chickens can introduce 
Syed et al., 2020

beneficial changes in gut microbiota. PLoS ONE, 13(3): e0194825 DOI: https://doi.org/10.1371/journal.pone.0194825

Brennan J, Skinner J, Barnum DA, and Wilson J (2003). The efficacy of bacitracin methylene disalicylate when fed in combination with narasin in the management of necrotic enteritis in broiler chickens. Poultry Science, 82: 360-363. DOI: https://doi.org/10.1093/ps/82.3.360

Brugaletta G, Cesare AD, Zampiga M, Laghi L, Oliver C, Zhu C, Manfreda G, Syed B, Valenzuela L, and Sirri F (2020). Effects of alternative administration programs of a synbiotic supplement on broiler performance, footpad dermatitis, caecal microbiota, and blood metabolites. animals, 10(3): 522. DOI: https://doi.org/10.3390/ani10030522

Dhama K, Verma V, Sawant PM, Tiwari R, Vaid RK, and Chauhan RS (2011). Applications of probiotics in poultry: Enhancing immunity and beneficial effects on production performances and health: A review. Journal of Immunology and Immunopathology, 13: 1-19. Available

at: www.indianjournals.com/ijor.aspx?target=ijor:jii\&volume=13\&is $\underline{\text { sue }}=1 \&$ article $=001$

Food and Agriculture Organization (FAO) and World Health Organization (WHO) (2002). Working group report on drafting guidelines for the evaluation of probiotics in food. 30 April-1 May, London, UK, and Ontario, Canada. FAO, Rome, Italy. Available https://www.who.int/foodsafety/fs_management/en/probiotic_guid elines.pdf

Fuentes CG, Orozco LA, Vicente JL, Velasco X, Menconi A, Kuttappan VA, Kallapura G, Latorre J, Layton S, Hargis BM and Tellez G (2013). Effect of a lactic acid bacteria based probiotic FloramaxB11, on performance, bone qualities, and morphometric analysis of broiler chickens. An Economic Analysis. Biological Systems, 12(6): 322-327. Available at: https://www.longdom.org/openaccess/effect-of-a-lactic-acid-bacteria-based-probioticfloramaxb11-on-performance-bone-qualities-and-morphometricanalysis-of-broilerchickens-an-economic-analysis-2329-65771000113.pdf

Gadde U, Kim WH, Oh, ST, and Lillehoj HS (2017). Alternatives to antibiotics for maximizing growth performance and feed efficiency in poultry: A review. Animal Health Research Reviews, 18: 26-45. DOI: https://doi.org/10.1017/S1466252316000207

Gaggia F, Mattarelli P, and Biavati B (2010). Probiotics and prebiotics in animal feeding for safe food production. International Journal of Food Microbiology, 141: S15-S28. DOI: https://doi.org/10.1016/j.ijfoodmicro.2010.02.031

Gustafson RH and Bowen RE (1997). Antibiotic use in animal agriculture A review. Journal of Applied Microbiology, 83: 531541. DOI: https://doi.org/10.1046/j.1365-2672.1997.00280.x

Huyghebaert G, Ducatelle R, and Van Immerseel F (2011). An update on alternatives to antimicrobial growth promoters for broilers. The $\begin{array}{llll}\text { Veterinary Journal, 187: 182-188. DOI: } & \end{array}$ https://doi.org/10.1016/j.tvj1.2010.03.003

Iji PA and Tivey DR (1998). Natural and synthetic oligosaccharides in broiler chicken diets. World's Poultry Science Journal, 54(02): 129-143. DOI: $\underline{\text { https://doi.org/10.1079/WPS19980010 }}$

Koenen ME, Kramer J, van der Hulst R, Heres L, Jeurissen SH, and Boersma WJ (2004). Immunomodulation by probiotic lactobacilli in layer- and meat-type chickens. Journal of British Poultry Science, 45(3): 355-366. Available at: https://www.tandfonline.com/doi/abs/10.1080/0007166041000173 $\underline{0851}$

Kogut MH and Swaggerty CL (2012). Effects of prebiotics and probiotics on the host immune response. Direct-Fed Microbials and Prebiotics for Animals, Pages 61-72 Springer publications. Available at: https://www.springer.com/gp/book/9781461413103
Kogut MH, Nan YX, Min YJ, and Broom L (2017). Gut health in poultry. CABI Wallingford UK, 12 . Available at: https://www.cabi.org/cabreviews/review/20173301742

Lee SI, Park SH, and Ricke SC (2016). Assessment of cecal microbiota, integron occurrence, fermentation responses, and Salmonella frequency in conventionally raised broilers fed a commercial yeast-based prebiotic compound. Poultry Science, 95: 144-153. DOI: https://doi.org/10.3382/ps/pev322

Mead GC (2000). Prospects for 'competitive exclusion' treatment to control salmonellas and other foodborne pathogens in poultry. The Veterinary Journal, 159: 111-123. DOI: https://doi.org/10.1053/tvjl.1999.0423

Mountzouris KC (2014). Probiotics as alternatives to antimicrobial growth promoters (AGPs) in broiler nutrition: modes of action and effects on performance. Probiotics in Poultry Production Concepts and Applications. Abdelrahman WHA, Mohnl M. editors, $5 \mathrm{~m}$ Publishing Ltd, Sheffield, UK, 129-157. Available at: https://www.amazon.com/Probiotics-Poultry-ProductionConcepts-Applications/dp/0955501180

Mountzouris KC, Palamidi I, Tsirtsikos P, Mohnl M, Schatzmayr G, and Fegeros K (2015). Effect of dietary inclusion level of a multispecies probiotic on broiler performance and two biomarkers of their caecal ecology. Animal Production Science, 55: 484-493. Available at: https://www.publish.csiro.au/an/an13358

Nava GM, Bielke LR, Callaway TR, and Castaneda MP (2005). Probiotic alternatives to reduce gastrointestinal infections: the poultry experience. Animal Health Research Reviews, 6(1): 105-118. DOI: https://doi.org/10.1079/AHR2005103

Niewold TA (2007). The nonantibiotic anti-inflammatory effect of antimicrobial growth promoters, the real mode of action? A hypothesis. Poultry Science, 86: 605-609. DOI: https://doi.org/10.1093/ps/86.4.605

Official methods of analysis (AOAC) (2016). 20th edition. Arlington: Association of official analytical chemists. Available at: https://www.techstreet.com/standards/official-methods-ofanalysis-of-aoac-international-20th-edition2016?product id=1937367

Oviedo-Rondon EO (2019). Holistic view of intestinal health in poultry. Animal Feed Science and Technology, 250: 1-8. DOI: https://doi.org/10.1016/j.anifeedsci.2019.01.009

Pedroso AA, Menten JFM, Lambais MR, Racanicci A MC, Longo FA, and Sorbara JOB (2006). Intestinal bacterial community and growth performance of chickens fed diets containing antibiotics. $\begin{array}{llll}\text { Poultry Science, 85: 747-752. DOI: } & \end{array}$ https://doi.org/10.1093/ps/85.4.747

Pelicano ERL, Souza PA, and Souza HBA (2004). Productive traits of broiler chickens fed diets containing different growth promoters. Brazilian Journal of Poultry Science, 6(3); 177-182. Available at: https://www.scielo.br/pdf/rbca/v6n3/a08v6n3.pdf

Roberfroid MB (1998). Prebiotics and synbiotics: concepts and nutritional properties. British Journal of Nutrition, 80 (Suppl. 2): 197-202. Available at: https://pubmed.ncbi.nlm.nih.gov/9924284/

Saarela M, Mogensen G, Fonden R, Mättö J, and Mattila-Sandholm T (2000). Probiotic bacteria: safety, functional and technological properties. Journal of Biotechnology, 84(3): 197-215. DOI: https://doi.org/10.1016/S0168-1656(00)00375-8

Snyder DL and Wostmann BS (1987). Growth rate of male germ-free Wister rats fed ad libitum or restricted natural ingredient diet. Laboratory Animal Science 37: 320-325. Available at: https://pubmed.ncbi.nlm.nih.gov/3613511/

Takahashi SE, MendesES AA, and Saldanha ESPB (2005). Efficiency of prebiotics and probiotics on the performance, yield, meat quality and presence of Salmonella spp in carcasses of free-range broiler chickens. Brazilian Journal of Poultry Science,7(3); 151-157. 
Tayeri V, Seidavi A, Asadpour L, and Phillips CJC (2018). A comparison of the effects of antibiotics, probiotics, synbiotics and prebiotics on the performance and carcass characteristics of broilers. Veterinary Research Communications, 42: 195-207. Available at: https://link.springer.com/article/10.1007/s11259$\underline{018-9724-2}$

Teirlynck E, Bjerrum L, Eeckhaut V, Huyghebaert G, Pasmans F, Haesebrouck F, Dewulf J, Ducatella R, and Immerseel FV (2009). The cereal type in feed influences gut wall morphology and intestinal immune cell infiltration in broiler chickens. British Journal of Nutrition, 102: 1453-1461. DOI: https://doi.org/10.1017/S0007114509990407

Wise MG and Siragusa GR (2007). Quantitative analysis of the intestinal bacterial community in one- to three-week-old commercially reared broiler chickens fed conventional or antibiotic-free vegetable-based diets. Journal of Applied Microbiology, 102: $1138-1149$ DOI: https://doi.org/10.1111/j.13652672.2006.03153.x

Yang C, Cao G, Ferket P, Liu T, Zhou L, Zhang L, Xiao Y, and Chen A (2012). Effects of probiotic, Clostridium butyricum, on growth performance, immune function, and cecal microflora in broiler chickens. Poultry Science, 91: 2121-2129. DOI: https://doi.org/10.3382/ps.2011-02131

Zhang Z and Kim I (2014). Effects of multi-strain probiotics on growth performance, apparent ileal nutrient digestibility, blood characteristics, cecal microbial shedding, and excreta odor contents in broilers. Poultry Science, 93: 364-370. DOI: https://doi.org/10.3382/ps.2013-03314 